\title{
RANCANGAN DOKUMEN DISASTER RECOVER PLAN PADA IS/ITDI DINAS XYZ
}

\author{
Zanuar Rifai $^{1}$, Andini Maydina ${ }^{2}$, Arief Adhy Kurniawan ${ }^{3}$ \\ ${ }^{1,2}$ Sistem Informasi STMIK AMIKOM Purwokerto
}

Jl. Letjen Pol Sumarto Watumas Purwanegara Purwokerto, 53123Indonesia

${ }^{3}$ Teknik InformatikaSTMIK AMIKOM Purwokerto

Jl. Letjen Pol Sumarto Watumas Purwanegara Purwokerto, 53123Indonesia

zanuar.rifai@amikompurwokerto.ac.id , amaydinaa@gmail.com²,ariefadhykurniawan@gmail.com³

\begin{abstract}
Abstrak-Tidak beroperasinya sistem informasi akibat kerusakan dan bencana sangat mempengaruhi proses bisnis dari sebuah Instansi. Tidak terkecuali instansi pemerintah Dinas XYZ Kabupaten Banyumas. Sehingga, Tindakan untuk memulihkan kembali sistem informasi yang tidak dapat beroperasi akibat kerusakan, dan kegagalan akibat bencana sangat diperlukan. Di sisi lain instansi Dinas XYZ Kabupaten Banyumas belum memiliki sebuah dokumen perencanaan pemulihan akibat bencana. Dokumen perencanaan pemulihan bencana adalah sebuah dokumen yang menjelaskan setiap prosedur yang harus dilakukan oleh sebuah institusi ketika menghadapi bencana sehingga dapat menyelamatkan aset pada sektor yang dimiliki sistem informasi pada Dinas XYZ Kabupaten Banyumas. Pada penelitian ini kami mengusulkan perancangan dokumen pemulihan akibat bencana yang disesuaikan dengan karakteristik Dinas XYZ Kabupaten Banyumas. Untuk mengetahui tingkat keberhasilan perancangan dokumen pemulihan akibat bencana kami melakukan pengujian dokumen tersebut dengan standar NIST SP 800-34. Berdasarkan hasil pengujian yang telah dilakukan, tindakan pemulihan terhadap masalah yang terjadi bisa dilakukan dengan yang lebih cepat.
\end{abstract}

Kata Kunci: Disaster Recovery Plan, NIST SP 800-34 Rev.1, Sistem Informasi.

Abstract - The malfunction of the information system due to damage and disaster greatly affect the business process of an agency. No exception government agencies XYZ Banyumas District. Thus, Actions to restore information systems that can not operate due to damage, and catastrophic failure are necessary. On the other hand, the Banyumas District Office of XYZ does not have a disaster recovery planning document. Disaster recovery planning document is a document that explains every procedure that an institution must take when facing a disaster so as to save assets in the sector owned by the information system at Banyumas District XYZ Office. In this study we propose the design of disaster recovery documents that are tailored to the characteristics of Banyumas District XYZ Office. To determine the success rate of disaster recovery document design we have tested the document with NIST SP 800-34 standard. Based on the results of tests that have been done, the recovery action to the problems that occur can be done with a faster.

Keywords: Disaster Recovery Plan, NIST SP 800-34 Rev.1, Information System

\section{PENDAhUluan}

Dalam meningkatkan nilai usaha, sebuah Instansi harus mempunyai sumber daya yang strategis salah satu sumber daya yang strategis adalah informasi, karena informasi adalah aset yang sangat krusial berharga bagi sebuah Instansi. Maka dari itu segenap jajaran, pemilik, manajemen dan karyawan wajib untuk melindungi Information System/Information Technology (IS/IT) secara sunggung-sungguh karena merupakan syarat mutlak perusahaan atau instansi yang bersangkutan[1][2][3]. Banyak Instansi atau perusahaan yang bergantung pada IS/IT untuk mendukung operasi bisnisnya sehari-hari termasuk didalam sektor pemerintahan. Dinas XYZ Kabupaten Banyumas merupakan instansi milik pemerintah yang dalam pelaksanaan tugas dan pekerjaannya tidak dapat lepas dari penggunaan IS/IT.
Perlindungan dilakukan padaIS/IT yang ada didalam perusahaan atau Instansi dari kejadian yang tak terduga seperti bencana baik bencana alam maupun non-alam yang dapat menyebabkan terjadinya kerugian-kerugian bagi kelangsungan hidup Instansi[3].

Bencana yang terjadi dapat berdampak langsung maupun tidak langsung terhadap operasional sebuah organisasi atau instansi. Organisasi atau instansi harus siap menghadapi dampak yang terjadi akibat bencana tersebut, dampak bencana tersebut sangat bervariasi seperti terhentinya jaringan komputer, terhentinya layanan IS/IT, terhentinya aliran listrik, supplier yang menghentikan supply produknya, ketidakhadiran pegawai, rusaknya fasilitas umum, keterlambatan pembayaran gaji dan lain sebagainya[4].

Indonesia merupakan kategori negara dengan risiko terjadinya bencana alam sangat besar, indonesia 
dalam posisi paling tinggi dalam peta rawan bencana. Bencana tersebut adalah gempa bumi, tsunami, tanah longsor dan letusan gunung berapi(BNPB, 2012). Selain bencana alam serangan hacker (DDoS, Web Deface, Virus, SQL Injection), Power Loss,Bandwidth Loss, Kehilangan Data, Human error juga berpotensi pada rusaknya peralatan yang dapat menimbulkan terhentinya suatu layanan IS/IT sehingga berdampak pada kerugian terhadap suatu institusi/perusahaan[5].

Perlu dibuatkan sebuah mekanisme penangan bencana yang mampu mengatasi dampak dari kerusakan bencana baik itu bencana alam dan kerusakan akibat perbuatan manusia. Karena itu perlu dibuatkan sebuah mekanisme untuk meminimalisir kerugian akibat bencana tersebut[6].

Adalah perencanaan pemulihan bencana yang merupakan dokumen yang memuat proses, kebijakan dan mekanisme yang berhubungan dengan persiapan pemulihan atau keberlangsungan infrastruktur teknologi yang kritis bagi Instansi atau perusahaan setelah terjadinya bencana, baik bencana yang disebabkan oleh tindakan manusia ataupun bencana alam[7][8]. Selain itu Disaster Recovery Plan merupakan bagian perencanaan dari sebuah institusi untuk melakukan tahapan tertentu yang nantinya akan menjamin kelangsungan pelayanan (khususnya dari segi IS/IT) yang diberikan tanpa mengurangi kapabilitas serta kinerja dari sebuah sistem jika terjadi sebuah bencana didalamnya. Faktor yang terpenting dalam sebuah Disaster Recovery Plan (DRP) adalah dari sisi corporate office. Karakteristik tiap orang, budaya Instansi serta tipe kepemimpinan dari sebuah Instansi sangatlah berpengaruh terhadap penyusunan serta implementasi dari Disaster Recovery Plan[9][10].

Pada paper ini kami membahas tentang perancangan Disaster Recovery Planpada Dinas XYZ Kabupaten Banyumas. Dalam pembahasannya, paper ini dibagi menjadi beberapa bagian. Bagian 1 adalah pendahuluan. Metode penelitian akan dibahas pada bab 2. Bab 3 menjelaskan hasil dan pembahasan, sedangkan kesimpulan akan disajikan pada bab 4.

\section{METODE PENELITIAN}

\section{A. Observasi.}

Didalam pembuatan prosedur Disaster Recovery Plan diperlukan data-data pendukung untuk prosedur Disaster Recovery Plan tersebut sehingga sesuai dengan IS/IT di Dinas XYZ Kabupaten Banyumas. Metode Observasi merupakan suatu metode untuk pengumpulan data dengan cara melakukan pengamatan secara langsung terhadap kondisi IS/IT di Dinas XYZ Kabupaten Banyumas[11]. Dari hasil pengamatan secara langsung tersebut, nantinya didapatkan suatu data yang digunakan sebagai acuan untuk pembuatan prosedur Disaster Recovery Plan.

Adapun data yang diperoleh dari hasil observasi IS/IT adalah sebagai berikut data bencana yang pernah terjadi terhadap IS/IT, data perangkat IS/IT baik perangkat keras maupun perangkat lunak. Dari data hasil observasi tersebut digunakan sebagai pembobotan untuk mendapatkan nilai yang digunakan sebagai atribut didalam menentukan potensi yang ditimbulkan dari suatu bencana.

\section{B. Studi dokumentasi}

Pada tahap studi dokumen ini, melakukan pengumpulan data melalui pencarian dan penemuan bukti-bukti yang tidak langsung ditujukan pada subjek penelitian, namun melalui dokumen. Pada penelitian tentang Disaster Recovery Plandokumen yang digunakan adalah dokumen tentang IS/ITdan topologi jaringan komputer di Dinas XYZ Kabupaten Banyumas. Didalam penelitian ini, data dari hasil dokumentasi sangat penting untuk analisa dan pembahasan lebih lanjut tentang prosedur Disaster Recovery Plan[11].

\section{Wawancara}

Wawancara merupakan suatu teknik pengumpulan data dengan mengajukan pertanyaan secara langsung oleh pewawancara (pengumpuldata) kepada responden dengan dicatat, ditulis atau diketik untuk jawaban responden[11]. Pada tahap teknik wawancara ini, dilakukan secara langsung di kampus Dinas XYZ Kabupaten Banyumas pada bagian IT khususnya yang menangani IS/IT. Pada bagian yang berwenang mengelola IS/IT akan diajukan beberapa pertanyaan untuk proses wawancara terkait dengan pengumpulan data untuk pembangunan Prosedur Disaster Recovery Plan terhadap IS/IT di Dinas XYZ Kabupaten Banyumas.

\section{Framework \& Metode Analisa Data}

Dalam membuat rancangan dokumen perancangan Disaster Recovery Plan ini, kerangka kerja yang digunakan adalah NIST SP 800-34 memuat prosedurprosedur antara lain kontrol pencegahan, strategi dan rencana kontigensi. Faktor utama yang dibutuhkan dalam perancangan Disaster Recovery Plan yaitu strategi yang digunakan untuk pemulihan aset IS/IT, penentuan teknologi pada masing-masing IS/IT, dan sumber daya manusia yang melaksanakan kegiatan [12].

Untuk memastikan rancangan dokumenRecovery Plan dapat diimplementasikan dengan baik, perlu tim Disaster Recovery Plan yang memiliki tugas yang sesuai dengan kemampuan yang dimiliki oleh masingmasing anggota. Perlu juga diperhatikan kondisi dan karakteristik yang dimiliki oleh oleh instansi yaitu instansi Dinas XYZ Kabupaten Banyumas ketika membentuk tim tersebut.

\section{HASIL DAN PEMBAHASAN}

\section{A. Skema Jaringan IS/IT}

Dinas XYZ Kabupaten Banyumas merupakan instansi pemerintah yang memanfaatkan IS/IT selama menjalankan kegiatan operasionalnya sehari-hari. Dengan mengimplementasikan IS/IT pada Dinas XYZ 
Kabupaten Banyumas maka diperlukan infrastruktur jaringan komputer untuk mengintegrasikan IS/IT yang digunakan. Pada tahun 2012 server pada Dinas XYZ Kabupaten Banyumas terkena petir yang mengakibatkan rusaknya 36 Komputer pada Dinas XYZ Kabupaten Banyumas[13]. kerusakan yang diakibatkan oleh suatu bencana baik itu bencana alam maupun akibat dari manusia perlu dibuat sebuah prosedur manajemen resiko yang mampu memitigasi resiko tersebut[14]. Oleh karena itu Disaster Recovery Plan (DRP) merupakan dokumen yang wajib dimiliki oleh instansi salah satunya adalah inas XYZ Kabupaten Banyumas untuk meminimalisir kerugian dan kerusakan akibat bencana tersebut.

Berikut skema dari jaringan komputer pada Dinas XYZ Kabupaten Banyumas:
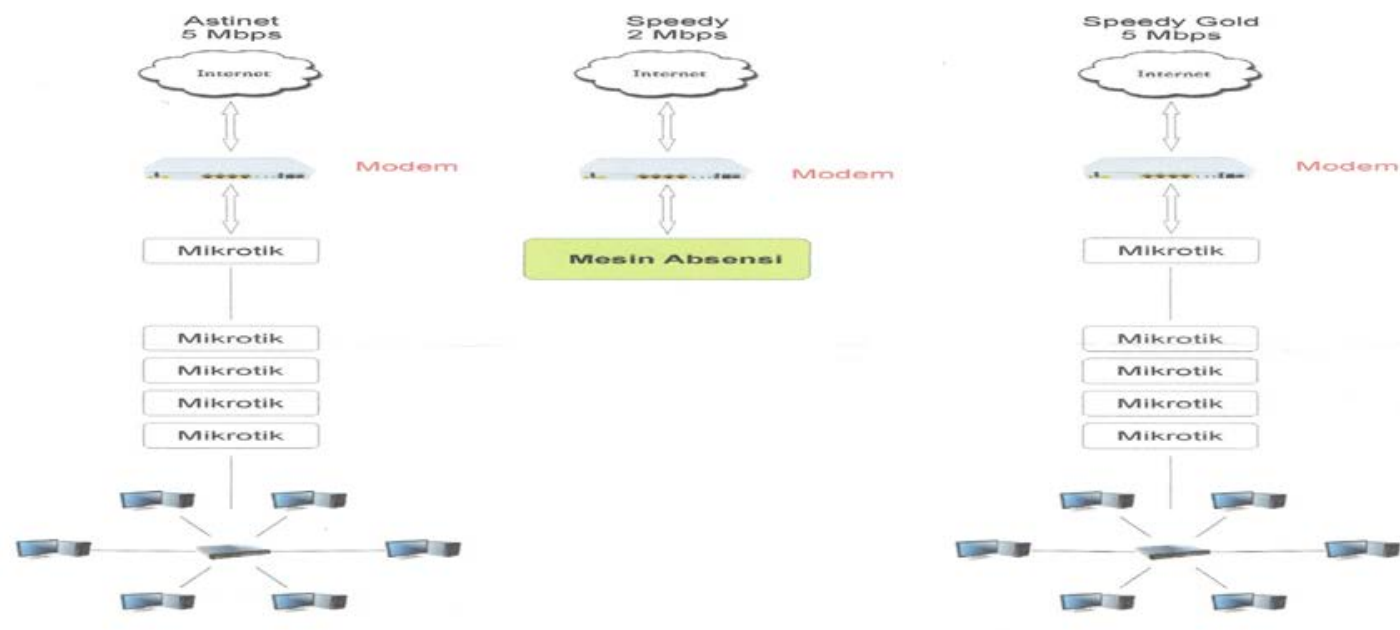

Gbr. 1 Skema Jaringan Komputer pada Dinas XYZ Kabupaten Banyumas[15]

\section{B. Sistem Informasi $X Y Z$}

Dalam menjalankan kegiatan operasionalnya sehari-hari, Dinas XYZ Kabupaten Banyumas menggunakan beberapa sistem informasi antara lain:

1) Sistem Informasi Manajemen Absensi Pegawai (SIMAP)

2) Sistem Informasi Pengelolaan Website dan SubDomain (SIWEDO).

3) Sistem Informasi Analisis Jabatan dan Evaluasi Jabatan (Si ANA)

4) Banyumas Mail (Email) merupakan akun surel Instansi Perangkat Desa (OPD)

5) PPDB Online.

6) Pengelolaan Calon Peserta Ujian Sekolah

Madrasah (USM) atau UN.

7) Satria Keuangan

8) Simbada Mas

\section{Risk Assesment}

Risk Assesment pada tahan ini berfokus pada ancaman yang dapat mempengaruhi aset-aset instansi yang ada hubungannya dengan pelaksanaan pelayanan publik[16]oleh Dinas XYZ Kabupaten Banyumas. Risk Assessment diperlukan untuk dapat menentukan

TABEL klasifikasi dampak dan penyebab terjadinya gangguan atau bencana yang mungkin terjadi dan berguna dalam penentuan langkah-langkah yang optimaluntuk memitigasi risiko yang terjadi.

Risiko yang terjadi pada gedung baik secara menyeluruh atau hanya sebagian dapat merusak dan menghancurkan aset-aset tersebut, misalnya pemadaman listrik berkepanjangan, gempa bumi, banjir, kebakaran, gunung meletus, kerusakan server, serangan virus, dan lain-lain. Menurut data yang diperoleh dari wawancara dengan Kasubbag Umum dan Kepegawaian Dinas XYZ Kabupaten Banyumas, pernah terjadi sambaran petir pada server Dinas XYZ Kabupaten Banyumas yang mengakibatkan rusaknya 36 komputer pada Dinas XYZ Kabupaten Banyumas.

Tahap Risk Assessment ini merupakan tahap pertama dari prosedur Disaster Recovery Plan. Risk Assessment digunakan untuk menentukan ancaman apa saja yang berpotensi menimbulkan risiko terhadap aset-aset yang ada di Dinas XYZ Kabupaten Banyumas. Berikut penjabaran mengenai ancaman yang dapat menimbulkan risiko beserta data mengenai kerentanan, aset penting serta konsekuensi dari ancaman yang terjadi:

RISK ASSESSMENT[13

\begin{tabular}{|l|l|l|c|c|c|}
\hline No. & Ancaman & Ancaman yang terjadi & Kerentanan & Aset Kritis & Konsekuensi \\
\hline 1 & Petir & Sambaran petir dapat & Petir dapat mengenai & Aset-aset & a. $\quad$ Berhentinya \\
\hline
\end{tabular}


CESS (Journal of Computer Engineering System and Science)

p-ISSN :2502-7131

Vol. 3 No. 2 Juli 2018

e-ISSN :2502-714x

Page | 150

\begin{tabular}{|c|c|c|c|c|c|}
\hline No. & Ancaman & Ancaman yang terjadi & Kerentanan & Aset Kritis & Konsekuensi \\
\hline & & $\begin{array}{l}\text { menyebabkan rusaknya } \\
\text { jaringan listrik atau LAN serta } \\
\text { alat-alat elektronik }\end{array}$ & $\begin{array}{l}\text { server yang } \\
\text { menyebabkan } \\
\text { kerusakan pada aset } \\
\text { Instansi }\end{array}$ & $\begin{array}{l}\text { perkantoran } \\
\text { dan } \\
\text { Gedung }\end{array}$ & $\begin{aligned} & \text { kegiatan } \\
& \text { b. } \text { Rerasional } \\
& \text { listrik atau LAN } \\
& \text { serta alat-alat } \\
& \text { elektronik }\end{aligned}$ \\
\hline 2 & Banjir & $\begin{array}{l}\text { Banjir dapat menimbulkan } \\
\text { kerusakan sarana dan } \\
\text { prasarana kantor }\end{array}$ & $\begin{array}{l}\text { Kerusakan yang } \\
\text { terjadi pada sarana dan } \\
\text { prasarana akibat banjir }\end{array}$ & $\begin{array}{l}\text { Aset-aset } \\
\text { perkantoran, } \\
\text { Gedung dan } \\
\text { karyawan }\end{array}$ & $\begin{array}{ll}\text { a. } & \text { Ketidakhadiran } \\
& \text { pegawai } \\
\text { b. } & \text { Sistem komputer } \\
& \text { dan komunikasi } \\
& \text { terpaksa } \\
& \text { dihentikan }\end{array}$ \\
\hline 3 & $\begin{array}{l}\text { Gempa } \\
\text { bumi }\end{array}$ & $\begin{array}{l}\text { Gempa bumi dapat merusak } \\
\text { infrastruktur yang ada pada } \\
\text { gedung jika melebihi kekuatan } \\
5 \text { dalam skala richter } \\
\end{array}$ & $\begin{array}{l}\text { Infrastruktur terletak } \\
\text { pada gedung yang } \\
\text { hanya tahan gempa } \\
\text { sampai } 5 \text { skala richter } \\
\end{array}$ & $\begin{array}{l}\text { Aset-aset } \\
\text { perkantoran } \\
\text { dan Gedung }\end{array}$ & $\begin{array}{l}\text { Terhentinya kegiatan } \\
\text { operasional instansi }\end{array}$ \\
\hline 4 & $\begin{array}{l}\text { Gunung } \\
\text { meletus }\end{array}$ & $\begin{array}{l}\text { Lava dan abu dari gunung } \\
\text { meletus dapat mengganggu } \\
\text { dan bahkan menghentikan } \\
\text { kegiatan operasional }\end{array}$ & $\begin{array}{l}\text { Lava dan abu dari } \\
\text { gunung berapi } \\
\text { menyebabkan seluruh } \\
\text { pegawai harus } \\
\text { dievakuasi dan } \\
\text { kegiatan operasional } \\
\text { terhenti } \\
\end{array}$ & $\begin{array}{l}\text { Aset-aset } \\
\text { perkantoran, } \\
\text { Gedung dan } \\
\text { karyawan }\end{array}$ & $\begin{array}{ll}\text { a. } & \text { Ketidakhadiran } \\
& \text { pegawai } \\
\text { b. } & \text { Terhentinya } \\
& \text { kegiatan } \\
& \text { operasional } \\
\text { instansi }\end{array}$ \\
\hline 5 & Kebakaran & \begin{tabular}{|ll} 
a. & Timbulnya api \\
b. & Akibat dari hubungan arus \\
& pendek aliran listrik atau \\
& yang lainnya
\end{tabular} & \begin{tabular}{|ll} 
a. & Gedung dapat \\
& terbakar atau \\
& menjadi bagian \\
& dari kebakaran \\
b. & Adanya material \\
& yang mudah \\
& terbakar pada \\
& setiap ruangan dan \\
& gedung
\end{tabular} & $\begin{array}{l}\text { Gedung dan } \\
\text { aset kantor }\end{array}$ & $\begin{array}{l}\text { Terhentinya kegiatan } \\
\text { operasional instansi }\end{array}$ \\
\hline 6 & $\begin{array}{l}\text { Listrik } \\
\text { mengalami } \\
\text { gangguan }\end{array}$ & 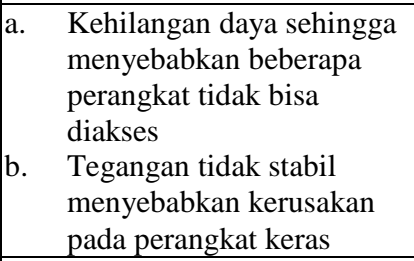 & \begin{tabular}{|l} 
Peralatan yang \\
membutuhkan aliran \\
listrik tidak berfungsi \\
sebagaimana mestinya
\end{tabular} & $\begin{array}{l}\text { Komputer, } \\
\text { aset kantor } \\
\text { dan } \\
\text { peralatan } \\
\text { kantor }\end{array}$ & $\begin{array}{l}\text { Kerusakan alat-alat } \\
\text { listrik dan jaringan }\end{array}$ \\
\hline 7 & Serverdown & $\begin{array}{l}\text { Server mengalami kerusakan } \\
\text { dan mengakibatkan down }\end{array}$ & \begin{tabular}{|l|} 
Server mengalami \\
kerusakan dan \\
mengakibatkan down \\
sehingga tidak bisa \\
diakses oleh pengguna \\
\end{tabular} & $\begin{array}{l}\text { Informasi, } \\
\text { komputer }\end{array}$ & Kerusakan server \\
\hline 8 & $\begin{array}{l}\text { Serangan } \\
\text { worm, } \\
\text { malware, } \\
\text { virus dan } \\
\text { sejenisnya }\end{array}$ & 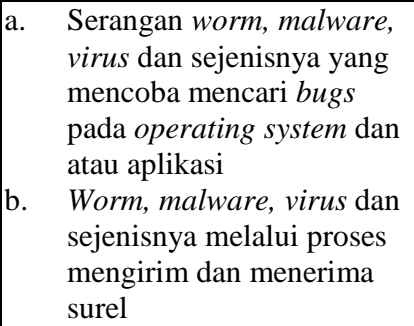 & \begin{tabular}{|ll} 
a. & aplikasi dan \\
& system operasi \\
& memiliki celah \\
b. & keamanan. \\
& lampiran pada \\
& surel dapat disisipi \\
& oleh virus
\end{tabular} & Informasi & Kehilangan data \\
\hline 9 & $\begin{array}{l}\text { Cyber } \\
\text { threat }\end{array}$ & $\begin{array}{l}\text { Adanya lubang keamanan } \\
\text { pada system jaringan } \\
\text { komputer oleh cracker untuk } \\
\text { masuk }\end{array}$ & $\begin{array}{l}\text { Penyalahgunaan akun } \\
\text { karena penggunaan } \\
\text { password yang lemah }\end{array}$ & $\begin{array}{l}\text { Informasi, } \\
\text { reputasi }\end{array}$ & $\begin{array}{ll}\text { a. } & \text { Bocornya } \\
& \text { informasi rahasia } \\
\text { b. } & \text { Rusaknya } \\
& \text { reputasi }\end{array}$ \\
\hline
\end{tabular}

Dari jenis ancaman yang terdapat pada tabel 1, Kabupaten Banyumas. Setelah didapatkan data ancaman seperti server down, virus, dan cyber threat dapat mengancam IS/IT yang ada pada Dinas XYZ 
tersebut digunakan sebagai acuan untuk tahap analisa dampak Business Impact Analysis (BIA).

\section{Business Impact Analysis (BIA)}

Business Impact Analysis atau analisis dampak

Page | 151 bisnis merupakan tahapan dalam pembuatan Disaster Recovery Plan (DRP) yang dilakukan untuk mengetahui proses bisnis mana yang merupakan proses bisnis yang vital dalam Instansi dan juga untuk mengetahui dampak yang akan dialami oleh Instansi jika terjadi gangguan atau bencana pada IS/IT yang menunjang proses bisnis tersebut[16]. Selain itu BIA juga digunakan untuk mengambil suatu keputusan manajemen atas Recovery Time Objective (RTO) dan Recovery Point Objective (RPO) untuk masingmasing fungsi bisnis atau proses layanan.

Business Impact Analysis (BIA) bertujuan untuk membantu suatu Instansi didalam memahami dampak yang diakibatkan dari suatu bencana yang tidak diharapkan, misalnya infrastruktur jaringan komputer down sehingga layanan tidak bisa digunakan baik untuk akses informasi maupun layanan email, IS/IT dan lain sebagainya. Sehingga diperlukan periode waktu yang bisa ditoleransi jika suatu layanan sistem lumpuh.

Maping layanan IS/IT dapat dilakukan untuk mengetahui layanan apa saja yang diberikan oleh sebuah IS/IT dalam melakukan pelayanan baik kepada internal instansi ataupun kepada masyarakat. Maping layanan sistem informasi ini dapat dilihat pada tabel 2.

TABEL II

MAPING LAYANAN SISTEM INFORMASI

\begin{tabular}{|l|l|l|}
\hline No. & \multicolumn{1}{|c|}{$\begin{array}{c}\text { Sistem } \\
\text { Informasi }\end{array}$} & \multicolumn{1}{|c|}{ Layanan } \\
\hline 1 & SIMAP & Manajemen absensi pegawai \\
\hline 2 & SIWEDO & $\begin{array}{l}\text { a. Media informasi } \\
\text { b. Pengaduan masyarakat }\end{array}$ \\
\hline 3 & $\begin{array}{l}\text { Banyumas } \\
\text { Mail }\end{array}$ & $\begin{array}{l}\text { Manajemen email Instansi } \\
\text { Perangkat Daerah (OPD) }\end{array}$ \\
\hline 4 & Si ANA & Analisis dan evaluasi jabatan \\
\hline 5 & PPDB Online & $\begin{array}{l}\text { Pendaftaran peserta didik baru } \\
\text { online }\end{array}$ \\
\hline 6 & $\begin{array}{l}\text { Pengelolaan } \\
\text { Capes } \\
\text { USM/UN }\end{array}$ & $\begin{array}{l}\text { Pendataan peserta Ujian Sekolah } \\
\text { Madrasah atau Ujian Nasional }\end{array}$ \\
\hline 7 & Satria & $\begin{array}{l}\text { Pengelolaan transaksi keuangan } \\
\text { Keuangan } \\
\text { XYZ Kabupaten Banyumas, } \\
\text { UPK, SKB dan sekolah }\end{array}$ \\
\hline 8 & Simbada Mas & $\begin{array}{l}\text { Pengelolaan aset Dinas XYZ } \\
\text { Kabupaten Banyumas, UPK, } \\
\text { SKB dan sekolah }\end{array}$ \\
\hline
\end{tabular}

Dinas XYZ Kabupaten Banyumas merupakan instansi pemerintahan yang mempunyai tugas melaksanakan operasional pemerintahan daerah secara teknis yang bergerak dalam bidang XYZ, tahapan berikutnya adalah menentukan IS/IT yang mempunyai tingkat kritis tinggi, sedang dan rendah berdasarkan peraturan dan tingkat reputasi instansi tersebut.

Berdasarkan wawancara yang telah dilakukan mengenai penentuan tingkat kritis suatu sistem informasi atau layanan yang ada pada Dinas XYZ Kabupaten Banyumas berdasarkan pada banyaknya masyarakat yang merasakan dampak dari sistem informasi atau layanantersebut. Berikut merupakan kategori tingkat dampak gangguan atau bencana terhadap bisnis, yaitu:

\section{a. Tinggi}

Sistem informasi mempunyai dampak dan efek samping yang signifikanterhadap instansi dan keberlangsungan sebuah organisasi selain itu berdampak juga pada pihak luar atau pengguna system yang ada hubungannya dengan masyarakat luas.

\section{b. Sedang}

IS/IT mempengaruhi aktivitas utama setiap unit kerja pada sebuah instansi dan juga mempunyai dampak serius terhadap instansi. selain itu berdampak pada hubungan dengan pihak luar instansi dalam lingkup kecil seperti instansi pemerintah diluar Instansi.

\section{c. Rendah}

Sistem informasi hanya berdampak pada kegiatan penunjang instansi atau hanya digunakan dalam lingkup internal dalam skala kecil instansi.

Selanjutnya, hasil analisis dampak bisnis dapat dilihat pada Tabel 3 Analisis dampak bisnis menggunakan Tabel 1 sebagai acuan. Pada Tabel 3 ini dijelaskan dampak seperti apa yang akan didapat apabila IS/IT yang ada pada Dinas XYZ Kabupaten Banyumas mengalami gangguan atau down. Juga dijelaskan mengenai tingkat dampak yang ditimbulkan terhadap bisnis.

TABEL III

PEMETAAN LAYANAN IS/IT

\begin{tabular}{|c|c|c|c|}
\hline No. & $\begin{array}{l}\text { Sistem } \\
\text { Informasi } \\
\text { (SI) }\end{array}$ & $\begin{array}{l}\text { Dampak yang dialami jika } \\
\text { SI down }\end{array}$ & $\begin{array}{l}\text { Tingkat } \\
\text { dampak }\end{array}$ \\
\hline 1 & SIMAP & $\begin{array}{l}\text { Informasi absensi pegawai } \\
\text { tidak dapat diketahui }\end{array}$ & Sedang \\
\hline 2 & SIWEDO & $\begin{array}{lrr}\text { Pengguna } & \text { tidak bisa } \\
\text { mengakses } & \text { informasi } \\
\text { mengenai Dinas XYZ } & \text { Xan } \\
\text { Kabupaten Banyumas, dan } \\
\text { reputasi Dinas XYZ } \\
\text { Kabupaten Banyumas akan } \\
\text { dipertanyakan }\end{array}$ & Sedang \\
\hline 3 & $\begin{array}{l}\text { Banyuma } \\
\text { s Mail }\end{array}$ & $\begin{array}{l}\text { Layanan email tidak bisa } \\
\text { digunakan, sehingga para } \\
\text { pegawai tidak dapat } \\
\text { mengirim } \\
\text { menggunakan email dinas }\end{array}$ & Rendah \\
\hline 4 & Si ANA & $\begin{array}{l}\text { Tidak dapat melihat dan } \\
\text { merubah data pegawai } \\
\text { sehingga tidak bisa } \\
\text { melakukan analisis dan } \\
\text { evaluasi }\end{array}$ & Sedang \\
\hline 5 & $\begin{array}{l}\text { PPDB } \\
\text { Online }\end{array}$ & $\begin{array}{l}\text { Pelayanan kepada calon } \\
\text { peserta didik baru tertunda }\end{array}$ & Tinggi \\
\hline 6 & Pengelola & Pengguna tidak & Tinggi \\
\hline
\end{tabular}




\begin{tabular}{|l|l|l|l|}
\hline & $\begin{array}{l}\text { an Capes } \\
\text { USM/UN }\end{array}$ & $\begin{array}{l}\text { melihat data dan } \\
\text { melakukan pendataan } \\
\text { peserta USM atau UN }\end{array}$ & \\
\hline 7 & $\begin{array}{l}\text { Satria } \\
\text { Keuanga } \\
\mathrm{n}\end{array}$ & $\begin{array}{l}\text { Tidak bisa menginput } \\
\text { laporan pelaksanaan } \\
\text { transaksi keuangan }\end{array}$ & Sedang \\
\hline 8 & $\begin{array}{l}\text { Simbada } \\
\text { Mas }\end{array}$ & $\begin{array}{l}\text { Kegiatan pengelolaan aset } \\
\text { tidak dapat dilakukan }\end{array}$ & Sedang \\
\hline
\end{tabular}

Menentukan Recovery Point Objective (RPO) dan Recovery Time Objective (RTO) dari setiap layanan IS/IT adalah tahapan selanjutnya untuk menganalisa dampak bisnis. Recovery Time Objective (RTO) merupakan waktu yang tersedia untuk memulihkan sistem dan sumber daya yang terganggu, sedangkan Recovery Point Objective (RPO) adalah banyaknya jumlah kehilangan data yang dapat ditoleransi oleh sistem bisnis kritis Instansi[16]. Untuk menentukan Recovery Time Objective (RTO) dan Recovery Point Objective (RPO) pengambilan datanya melalui wawancara langsung dengan penanggung jawabIS/IT pada instansi tersebut, hasil dari data tersebut ditampilkan ada pada Tabel 4

TABEL IV

IDENTIFIKASI RECOVERY TIME OBJECTIVE DAN RECOVERY POINT OBJECTIVE

\begin{tabular}{|l|l|l|l|l|}
\hline No. & \multicolumn{1}{|c|}{$\begin{array}{c}\text { Sistem } \\
\text { Informasi }\end{array}$} & $\begin{array}{c}\text { Recovery } \\
\text { Time } \\
\text { Objective }\end{array}$ & $\begin{array}{l}\text { Recovery } \\
\text { Point } \\
\text { Objective }\end{array}$ & $\begin{array}{c}\text { Tingkat } \\
\text { Dampa } \\
\mathrm{k}\end{array}$ \\
\hline 1 & SIMAP & $1-7$ jam & $1-7$ jam & Sedang \\
\hline 2 & SIWEDO & $1-7$ jam & $1-7$ jam & Sedang \\
\hline 3 & $\begin{array}{l}\text { Banyumas } \\
\text { Mail }\end{array}$ & $1-7$ jam & $1-7$ jam & Rendah \\
\hline 4 & Si ANA & $1-7$ jam & $1-7$ jam & Sedang \\
\hline 5 & PPDB Online & $\begin{array}{l}14-24 \\
\text { jam }\end{array}$ & $\begin{array}{l}14-24 \\
\text { jam }\end{array}$ & Tinggi \\
\hline 6 & $\begin{array}{l}\text { Pengelolaan } \\
\text { Capes }\end{array}$ & $\begin{array}{l}12-24 \\
\text { jam }\end{array}$ & $\begin{array}{l}14-24 \\
\text { jam }\end{array}$ & Tinggi \\
\hline 7 & $\begin{array}{l}\text { Satria } \\
\text { Keuangan }\end{array}$ & $\begin{array}{l}14-24 \\
\text { jam }\end{array}$ & $\begin{array}{l}14-24 \\
\text { jam }\end{array}$ & Sedang \\
\hline 8 & Simbada Mas & $\begin{array}{l}14-24 \\
\text { jam }\end{array}$ & $\begin{array}{l}14-24 \\
\text { jam }\end{array}$ & Sedang \\
\hline
\end{tabular}

Tahapan terakhir dalam proses analisa ini adalah menentukan IS/IT yang prioritas pada Dinas XYZ Kabupaten Banyumas. Dalam menentukan prioritas IS/IT dilakukan dengan cara mengolah hasil dari analisis dampak risiko terhadap bisnis Instansi dan penentuan nilai Recovery Time Objective dan Recovery Point Objective dari masing-masing IS/IT.

IS/IT yang mempunyai prioritas tertinggi Dinas XYZ Kabupaten Banyumas adalah pengelolaan Capes USM/UN karena sebagai sistem tersebut merupakan sistem penunjang pelayanan ke sekolah atau madrasah. Selain itu sistem ini juga menyimpan data mengenai calon peserta ujian. Setelah itu PPDB Online yang dimiliki oleh Dinas XYZ Kabupaten Banyumas, karena juga berhubungan dengan pelayanan kepada sekolah atau madrasah. Kedua IS/IT ini juga dipegang dan dijalankan oleh pihak ketiga yaitu dari Dinas XYZ Provinsi Jawa Tengah.

Selanjutnya Satria Keuangan menjadi prioritas berikutnya karena sistem ini merupakan sistem pengelolaan transaksi keuangan pada Dinas XYZ Kabupaten Banyumas, UPK, SKB dan sekolah. Simbada Mas menjadi prioritas selanjutnya karena berhubungan dengan pengelolaan aset-aset yang ada pada Dinas XYZ Kabupaten Banyumas. SIMAP menjadi prioritas selanjutnya karena berhubungan dengan manajemen absensi pegawai. Jika terjadi gangguan pada sistem ini maka informasi mengenai absensi pegawai tidak akan diketahui.

SIWEDO menjadi prioritas IS/IT berikutnya, karena sistem ini adalah media informasi kepada masyarakat. Si ANA menjadi prioritas IS/IT selanjutnya karena sistem ini menyediakan data pegawai beserta jabatannya. Kalau sistem ini terganggu, maka kegiatan analisis dan evaluasi tidak dapat dilakukan. Lalu urutan prioritas terakhir adalah Banyumas Mail. Banyumas Mail ini digunakan sebagai manajemen email OPD. Apabila sistem ini terganggu maka para pegawai tidak bisa mengirimkan email melalui email dinas dan para pegawai masih bisa menggunakan layanan email selain email dinas seperti layanan email dari google dan yahoo yang keamanannya masih rentan. Selanjutnya penentuan prioritas IS/IT mengikuti hasil penilaian risiko dan penentuan dampak terhadap Instansi disajikan pada Tabel 5

TABEL V

PRIORITAS PEMULIHAN SISTEM INFORMASI

\begin{tabular}{|c|l|c|}
\hline Prioritas & \multicolumn{1}{|c|}{ Sistem Informasi } & $\begin{array}{c}\text { Urutan } \\
\text { Prioritas }\end{array}$ \\
\hline Tinggi & Pengelolaan Capes USM/UN & 1 \\
\hline Tinggi & PPDB Online & 2 \\
\hline Sedang & Satria Keuangan & 3 \\
\hline Sedang & Simbada Mas & 4 \\
\hline Sedang & SIMAP & 6 \\
\hline Sedang & SIWEDO & 7 \\
\hline Sedang & Si ANA & 8 \\
\hline Rendah & Banyumas Mail & 6 \\
\hline
\end{tabular}

\section{E. Startegy Recovery}

Strategy Recovery merupakan proses untuk melakukan pemulihan ketika terjadi suatu kegagalan pada sistem. Didalam melakukan proses Recovery terdapat beberapa hal yang perlu diketahui seperti penyediaan fasilitas baik perangkat keras maupun perangkat lunak yang berguna untuk pemulihan layanan. Dari hasil Risk Assessment dan Business Impact Analysis dapat diambil jenis-jenis ancaman yang mampu menjadi acuan untuk melakukan proses recovery. Untuk menentukan proses strategi pemulihan (strategy recovery) perlu 
mempertimbangkan lingkup kerusakan yang disebabkan oleh gangguan atau bencana.

Ancaman terhadap IS/IT dapat dilihat dari atributatribut ancaman pada Risk Assessment yang memerlukan suatu strategi pemulihan. Berikut ini tabel proses pemulihan terhadap sistem informasi pada Dinas XYZ Kabupaten Banyumas.

TABEL VI

PROSES PEMULIHAN SISTEM INFORMASI

\begin{tabular}{|c|c|c|c|}
\hline No. & $\begin{array}{c}\text { Ganggua } \\
n\end{array}$ & Kendala & Proses Recovery \\
\hline 1 & $\begin{array}{l}\text { Server } \\
\text { down }\end{array}$ & $\begin{array}{l}\text { Server mengalami } \\
\text { kerusakan dan } \\
\text { mengakibatkan } \\
\text { down, sehingga } \\
\text { tidak bisa diakses } \\
\text { oleh pengguna }\end{array}$ & $\begin{array}{l}\text { Diganti dengan } \\
\text { menggunakan } \\
\text { server cadangan }\end{array}$ \\
\hline 2 & $\begin{array}{l}\text { Listrik } \\
\text { mengala } \\
\text { mi } \\
\text { gangguan }\end{array}$ & \begin{tabular}{|l} 
a. Kehilangan \\
daya \\
menyebabkan \\
beberapa \\
perangkat tidak \\
bisa diakses \\
b. Tegangan tidak \\
stabil \\
menyebabkan \\
kerusakan pada \\
perangkat keras
\end{tabular} & $\begin{array}{l}\text { Menambah } \\
\text { perangkat UPS } \\
\text { untuk mencegah } \\
\text { perangkat mati } \\
\text { secara tiba-tiba } \\
\text { dan } \\
\text { menyebabkan } \\
\text { kerusakan parah }\end{array}$ \\
\hline 3 & $\begin{array}{l}\text { Sistem } \\
\text { terinfeksi } \\
\text { virus }\end{array}$ & $\begin{array}{l}\text { a. Sistem operasi } \\
\text { menjadi lambat } \\
\text { b. Beberapa file } \\
\text { hilang karena } \\
\text { diduplikat oleh } \\
\text { virus }\end{array}$ & $\begin{aligned} & \text { a. } \text { Menggunakan } \\
& \text { anti virus dan } \\
& \text { melakukan } \\
& \text { scanning } \\
& \text { secara rutin } \\
& \text { b. } \text { Melakukan } \\
& \quad \text { repair } \\
& \quad \text { terhadap } \\
& \text { sistem } \\
& \text { informasi } \\
&\end{aligned}$ \\
\hline 4 & $\begin{array}{l}\text { Cyber } \\
\text { threat }\end{array}$ & \begin{tabular}{|l} 
a. \\
kerdapat celah \\
jaringan \\
komputer \\
b. Bocornya \\
informasi \\
rahasia yang \\
diambil oleh \\
hacker
\end{tabular} & $\begin{array}{l}\text { a. Penggunaan } \\
\text { password } \\
\text { yang kuat } \\
\text { dengan } \\
\text { kombinasi } \\
\text { huruf dan } \\
\text { angka } \\
\text { b. Pergantian } \\
\text { password } \\
\text { secara rutin } \\
\end{array}$ \\
\hline 5 & SIMAP & \begin{tabular}{|l} 
a. \\
informastem \\
mengalami \\
error dan \\
informasi \\
absensi pegawai \\
tidak bisa \\
diakses \\
b. Database \\
mengalami \\
error sehingga \\
tidak bisa \\
diakses \\
\end{tabular} & $\begin{array}{l}\text { a. } \text { Melakukan } \\
\text { pengecekan } \\
\text { didalam } \\
\text { coding dan } \\
\text { koneksi ke } \\
\text { database } \\
\text { b. } \text { Melakukan } \\
\text { backup sistem } \\
\text { informasi }\end{array}$ \\
\hline 6 & SIWEDO & \begin{tabular}{|l|} 
Informasi \\
mengenai Dinas \\
XYZ Kabupaten \\
\end{tabular} & $\begin{array}{l}\text { Melakukan } \\
\text { pengecekan } \\
\text { didalam coding }\end{array}$ \\
\hline
\end{tabular}

\begin{tabular}{|c|c|c|c|}
\hline No. & $\underset{\mathrm{n}}{\text { Ganggua }}$ & Kendala & Proses Recovery \\
\hline & & $\begin{array}{l}\text { Banyumas tidak } \\
\text { bisa diakses dan } \\
\text { reputasi Dinas } \\
\text { XYZ Kabupaten } \\
\text { Banyumas akan } \\
\text { dipertanyakan }\end{array}$ & $\begin{array}{l}\text { dan koneksi ke } \\
\text { database }\end{array}$ \\
\hline 7 & $\begin{array}{l}\text { Banyuma } \\
\text { s Mail }\end{array}$ & $\begin{array}{l}\text { Layanan email } \\
\text { tidak bisa } \\
\text { digunakan } \\
\text { sehingga para } \\
\text { pegawai tidak } \\
\text { dapat mengirim } \\
\text { email } \\
\text { menggunakan } \\
\text { email dinas } \\
\end{array}$ & $\begin{array}{l}\text { Menggunakan } \\
\text { email lain } \\
\text { seperti gmail, } \\
\text { yahoo dan lain- } \\
\text { lain }\end{array}$ \\
\hline 8 & Si ANA & $\begin{array}{l}\text { a. Sistem } \\
\text { informasi } \\
\text { mengalami } \\
\text { error dan data } \\
\text { pegawai tidak } \\
\text { bisa diakses } \\
\text { sehingga tidak } \\
\text { dapat } \\
\text { melakukan } \\
\text { analisis dan } \\
\text { evaluasi } \\
\text { b. Database } \\
\text { mengalami } \\
\text { error sehingga } \\
\text { tidak bisa } \\
\text { diakses } \\
\end{array}$ & $\begin{array}{l}\text { a. Melakukan } \\
\text { pengecekan } \\
\text { didalam } \\
\text { coding dan } \\
\text { koneksi ke } \\
\text { database } \\
\text { b. Melakukan } \\
\text { backup sistem } \\
\text { informasi }\end{array}$ \\
\hline 9 & $\begin{array}{l}\text { PPDB } \\
\text { Online }\end{array}$ & $\begin{array}{l}\text { a. } \text { Sistem } \\
\text { informasi } \\
\text { mengalami } \\
\text { error dan tidak } \\
\text { bisa diakses } \\
\text { b. Pelayanan } \\
\text { kepada calon } \\
\text { peserta didik } \\
\text { baru menjadi } \\
\text { tertunda }\end{array}$ & $\begin{array}{l}\text { a. Melakukan } \\
\text { pengecekan } \\
\text { didalam } \\
\text { coding dan } \\
\text { koneksi ke } \\
\text { database } \\
\text { b. Melakukan } \\
\text { backup sistem } \\
\text { informasi }\end{array}$ \\
\hline 10 & $\begin{array}{l}\text { Pengelola } \\
\text { an Capes } \\
\text { USM/UN }\end{array}$ & $\begin{array}{l}\text { a. } \text { Sistem } \\
\text { informasi } \\
\text { mengalami } \\
\text { error dan data } \\
\text { mengenai calon } \\
\text { peserta } \\
\text { USM/UN tidak } \\
\text { bisa diakses } \\
\text { b. Database } \\
\text { mengalami } \\
\text { error sehingga } \\
\text { tidak bisa } \\
\text { diakses } \\
\end{array}$ & $\begin{array}{l}\text { a. Melakukan } \\
\text { pengecekan } \\
\text { didalam } \\
\text { coding dan } \\
\text { koneksi ke } \\
\text { database } \\
\text { b. Melakukan } \\
\text { backup sistem } \\
\text { informasi }\end{array}$ \\
\hline 11 & $\begin{array}{l}\text { Satria } \\
\text { Keuanga } \\
\mathrm{n}\end{array}$ & $\begin{array}{l}\text { a. Sistem } \\
\text { informasi } \\
\text { mengalami } \\
\text { error dan } \\
\text { laporan } \\
\text { pelaksanaan } \\
\text { transaksi } \\
\text { keuangan tidak } \\
\text { bisa diinput }\end{array}$ & $\begin{array}{l}\text { a. Melakukan } \\
\text { pengecekan } \\
\text { didalam } \\
\text { coding dan } \\
\text { koneksi ke } \\
\text { database } \\
\text { b. Melakukan } \\
\text { backup sistem } \\
\text { informasi }\end{array}$ \\
\hline
\end{tabular}




\begin{tabular}{|c|c|c|c|}
\hline \multirow[t]{2}{*}{ No. } & Ganggua & Kendala & Proses Recovery \\
\hline & & $\begin{array}{l}\text { b. Database } \\
\text { mengalami } \\
\text { error sehingga } \\
\text { tidak bisa } \\
\text { diakses } \\
\end{array}$ & \\
\hline 12 & $\begin{array}{l}\text { Simbada } \\
\text { Mas }\end{array}$ & $\begin{array}{l}\text { a. Sistem } \\
\text { informasi } \\
\text { mengalami } \\
\text { error dan } \\
\text { kegiatan } \\
\text { pengelolaan } \\
\text { aset tidak dapat } \\
\text { dilakukan } \\
\text { b. Database } \\
\text { mengalami } \\
\text { error sehingga } \\
\text { tidak bisa } \\
\text { diakses }\end{array}$ & $\begin{array}{l}\text { a. Melakukan } \\
\text { pengecekan } \\
\text { didalam } \\
\text { coding dan } \\
\text { koneksi ke } \\
\text { database } \\
\text { b. Melakukan } \\
\text { backup sistem } \\
\text { informasi }\end{array}$ \\
\hline
\end{tabular}

\section{F. Dokumentasi}

Dokumentasi Disaster Recovery Plan merupakan tahap mendokumentasikan prosedur Disaster Recovery Plan (DRP). Langkah-langkah penyusunan dokumentasi DRP menggunakan standar framework NIST SP 800-34 Rev.1 dan nantinya dokumen ini akan diterapkan di Dinas XYZ Kabupaten Banyumas untuk mendukung proses penanggulangan jika terjadi gangguan atau bencana pada Dinas XYZ Kabupaten Banyumas.

\section{PENUTUP}

Berdasarkan penelitian yang telah dilakukan, maka dapat diambil beberapa kesimpulan sebagai berikut:

1. Hasil akhir berupa dokumen Disaster Recovery Plan yang didalamnya berisi prosedur-prosedur Disaster Recovery Plan yang dapat dijadikan sebagai masukan dalam pembuatan dan penerapan rencana pemulihan setelah terjadinya bencana pada Dinas XYZ Kabupaten Banyumas.

2. Disaster Recovery PlanIS/IT pada Dinas XYZ Kabupaten Banyumas dirumuskan melalui tahapan Risk Assessment, Business Impact Analysis (BIA), Strategy Recovery, Dokumentasi Disaster Recovery Plan, sampai dengan Testing.

3. Pembuatan Disaster Recovery Plan disesuaikan dengan situasi dan kondisi yang ada pada Dinas XYZ Kabupaten Banyumas agar perencanaan dan penanganannya dapat dilakukan secara tepat.

\section{UCAPAN TERIMAKASIH}

Terima kasih penulis sampaikan kepada STMIK AMIKOM Purwokerto, yang telah mendukung penelitian ini.

\section{REFERENSI}

[1] P. R. E. Indrajit, Konsep dan Strategi Keamanan Informasi di Dunia Cyber. Yogyakarta: Graha Ilmu, 2014.

[2] R. Budiarto, "Manajemen Risiko Keamanan Sistem Informasi,” vol. 2, no. 2, pp. 48-58, 2017.

[3] Yakub, Pengantar Sistem Informasi. Yogyakarta: Graha Ilmu,
2012.

[4] P. P. Ardhiatno, "Perancangan business ...., Prabowo Priyo Ardhiatno, Fasilkom UI, 2013,” 2013.

[5] Pemerintah Republik Indonesia, Undang-Undang Republik Indonesia Nomor 24 Tahun 2007 tentang Penanggulangan Bencana. Indonesia, 2007.

[6] J. C. Daud, "Pembuatan Disaster Recovery Plan (DRP) Berdasarkan ISO / IEC 24762 : 2008 Di ITS Surabaya ( Studi Kasus di Pusat Data dan Jaringan BTSI ITS ),” J. Tek. Pomits, 2008.

[7] N. Rachmaningrum, "Studi Kelayakan Disaster Recovery Plan pada Infrastruktur Jaringan Komputer (Studi kasus Jaringan Komputer Universitas Widyatama),” in semnasIF 2011 UPN Veteran Yogyakarta, 2011, vol. 2011, no. semnasIF, pp. 30-36.

[8] A. F. U. Fahmawati, "Faktor-Faktor yang Mempengaruhi Disaster Recovery Plan dan Business Continuity Planning," Universitas Lampung, 2016.

[9] I WAYAN ARDI YASA, "Perumusan Disaster Recovery Plan Pada Infrastruktut Jaringan Komputer(Studi Kasus STMIK STIKOM Bali),” 2016.

[10] R. Soetam, Disaster Recovery Plan. Jakarta: Prestasi Pustaka, 2008.

[11] Jogiyanto, Sistem Teknologi Informasi. Yogyakarta: Andi, 2005.

[12] NIST, Contingency Planning Guide for Federal Information Systems, National Institute of Standards and Technology. U.S Department of Commerce, 2010.

[13] Dinas Pendidikan Kabupaten Banyumas, "Wawancara Bencana Yang Pernah Terjadi,” 2017.

[14] H. faqih Zanuar Rifai, "Perancangan Business Continuty Plan (Bcp) Layanan Sistem Informasi Stmik Amikom Purwokerto (Studi Kasus : Stmik Amikom Purwokerto)," Probisnis, vol. 10, no. 2, 2017.

[15] Dinas Pendidikan Kabupaten Banyumas, "Topologi Jaringan Sistem Informasi,” Banyumas, 2017.

[16] R. L. Tammineedi, "Business continuity management: A standards-based approach,” Inf. Secur. J., vol. 19, no. 1, pp. 36-50, 2010. 